\title{
PERMAINAN TRADISIONAL BAGI ANAK USIA DINI DI KALIMANTAN BARAT
}

\author{
Lukmanulhakim \\ Pendidikan Guru Pendidikan Anak Usia Dini, Universitas Tanjungpura, Pontianak \\ E-mail:lukmanulhakim@fkip.untan.ac.id
}

\begin{abstract}
West Kalimantan local treasures are a potential that needs to be maintained and developed, one of which is the traditional games. This research focuses on conducting an inventory of traditional games for early childhood in Kalbar. This study uses a qualitative approach. The source of this research is the community consisting of Community Leaders of Kalbar, The Indonesian local sport federation (FORMI), Communities, children, parents. The research methods used were in-depth interviews, observation, and documentation studies. The study concludes that traditional Kalbar games that have potential for early childhood development are Gasing, Jajak Sisir, Ukau, Jangkak Tempurung, Lantak/leletop, Tabak Oka/Dengkak, Jangko, Stabbing Rusak, Galah Kepung/Galasin, and Tapok Beleg/Canned. There are two types of games found in the ten traditional games: solitary and cooperative play. The characteristics of the traditional games found are the cultural heritage of the Kalbar's people. The game is identical to using natural materials as a medium. Each game has its own rules of play. Traditional games have development potential for early childhood.
\end{abstract}

Keywords: Traditional Games, Early Childhood, West Kalimantan

\begin{abstract}
Abstrak
Kekayaan yang dimiliki oleh masyarakat Kalimantan Barat (Kalbar) merupakan potensi yang perlu dijaga serta dikembangkan, salah satunya kekayaan permainan tradisional. Fokus penelitian ini adalah melakukan inventarisasi permainan tradisioanl bagi anak usia dini di Kalbar. Penelitian ini menggunakan pendekatan kualitatif. Kegiatan penelitian ini berlokasi di Kalbar. Sumber dari penelitian ini adalah masyarakat yang terdiri dari: Tokoh Masyarakat Kalbar, Komunitaskomunitas, Federasi Olahraga Rakyat Masyarakat Indonesia (FORMI), anak-anak, para orang tua. Metode penelitian yang digunakan adalah wawancara mendalam, observasi; dan studi dokumentasi. Penelitian ini menyimpulkan bahwa permainan tradisional Kalbar menjadi potensi bagi pengembangan anak usia dini yaitu Gasing, Jajak Sisir, Ukau, Jangkak Tempurung, Lantak/ leletop, Tabak Oka/ Dengkak, Jangko, Tikam Rusak, Galah Kepung/ Galasin, dan Tapok Beleg/ Kaleng. (1) Jenisjenis permainan yang ditemukan dalam sepuluh permainan tradisonal terbagi dalam dua jenis. yaitu solitary play dan cooperative play. (2) Karakteristik permainan tardisional yang ditemukan merupakan warisan budaya masyarakat Kalbar. (3) Permainan identik dengan pemanfataan bahan alam sebagai medianya. (4) Setiap permainan memiliki aturan bermainnya masing-masing. (5) Permainan tradisional memiliki potensi pengembangan bagi anak usia dini.
\end{abstract}

Kata Kunci: Permainan Tradisional, Anak Usia Dini, Kalimantan Barat.

PENDAHULUAN

Provinsi Kalimantan Barat merupakan salah satu propinsi di Indonesia yang luas $(146.807 \mathrm{~m} 2 / 7 \%$ dari luas Indonesia, terbesar ke 4) dan memiliki kekayaan budaya.

Kekayaan yang dimiliki oleh masyarakat Kalimantan Barat 
merupakan potensi yang perlu dijaga serta dikembangkan. Dalam konteks budaya, keberagaman budaya menghasilkan produk-produk kebudayaan yang bervariatif, konpetitif dan konservatif.

Kebudayaan merupakan pondasi dalam membangun peradaban bangsa. Budaya nasional berakar pada budaya lokasi dari segenap bangsa Indonesia.

Potensi alam dan sosial Kalimantan Barat membentuk tatanan kebudayaan yang khas. Kebudayaan menghasilkan produk-produk yang menjadi warisannya yang muncul dalam bentuk beragam misalnya seni tari, cara berpakaian, ritual, symbol, tradisi, nilai dan sebagainya (Hofdtede, dkk (dalam Pangabean, 2014: 17)).

Merespon perkembangan budaya pada zaman modern saat ini, permainan tradisional yang menjadi aktivitas sosial turun-temurun sebagai tranformasi dan konservasi semakin tergerus oleh zaman. Pada aman modern yang berkembang saat ini, kita melihat banyak fenomena yang perlu menjadi perhatian.

Permainan tradisional saat ini menjadi tabu dalam masyarakat, khususnya anak usia dini. Kegiatan permaian anak-anak sudah dikemas lebih modern dan berorientasi pada pengembangan individu.

Bentuk lebih detail, berbantuan komputer dan elektronika, dan individualistik. Banyak permainan yang saat ini sedang berkembang, diantaranya gadget, komputer online, dan robot karakter, dan sebagainya. Permainan tradisonal menjadi barang langka dalam aktivitas anak usia dini.

Hal ini terjadi pula pada kegiatankegiatan anak usia dini di Kalimantan Barat. Keragaman budaya di Kalimantan Barat seharusnya memberikan kita pengalaman yang berkelanjutan termasuk dalam permainan tradisionalnya. Namun dokumen-dokumen tentang permainan tradisonal Kalimantan Barat merupakan barang langka. Dalam dunia pendidikan anak usia dini kita belum banyak mendengar pengintegrasian kurikulum muatan lokal dalam sistem dan kegiatan pembelajaran yang ada. Hal ini sangat memprihatinkan bagi generasi bangsa ini.

Kita perlu menyadari bahwa pengalaman merupakan proses pendidikan dengan makna yang luas (Mudyahardjo, 2005:47). Dan pendidikan merupakan proses transformasi budaya (Umar Tirtarahardja \& Sulo La Sulo, 2005:33).

Melihat fenomena di atas penulis merasa perlu melakukan upaya konservatif. Upaya tersebut dilakukan dalam bentuk inventarisasi permainan tradisonal khas Kalimantan Barat. Kegiatan inventarisasi ini diharapkan dapat menghasilkan dokumen dalam bentuk buku, katalog, maupun media publikasi lain yang dapat diakses oleh orang tua, pendidik maupun masyarakat yang terlibat dalam pengembangan anak usia dini.

Dari identifikasi masalah yang dilakukan, dipilih fokus penelitian ini adalah melakukan inventarisasi permainan tradisioanl bagi anak usia dini di Kalimantan Barat.

\section{METODE}

Penelitian menggunakan pendekatan kualitatif. Alasan pemilihan pendekatan ini agar dapat mengungkapkan fenomena sosial secara detail, khususnya tentang permainan tradisional pada masyarakat Kalimantan Barat.

Kegiatan penelitian ini berlokasi di wilayah Kalimantan Barat. Sumber dari penelitian ini adalah masyarakat yang terdiri dari: Tokoh Masyarakat Kalimantan Barat, Komunitaskomunitas, Federasi Olahraga Rakyat Masyarakat Indonesia (FORMI), anakanak, para orang tua.

Upaya untuk memperoleh data 
secara lengkap sesuai rumusan masalah penelitian, maka peneliti menggunakan metode penelitian berikut ini: (a) wawancara mendalam; (b) observasi; dan (c) studi dokumentasi.

Instrumen penelitian ini adalah peneliti sendiri. Keuntungan peneliti sebagai instrumen penelitian karena sifatnya responsive dan adaptable sehingga data atau informasi yang didapatkan akan lebih komprehenshif.

Analisis data penelitian kualitatif melalui tiga tahapan yang saling terintegrasi, yakni: reduction, display dan verification.

Peneliti melakukan pengujian keabsahan atau validitas, melalui berbagai teknik, yakni: (a) observasi terus menerus; (b) triangulasi; metode, sumber, penelitian lain; (c) pengecekan anggota; (d) diskusi teman sejawat; dan (e) mengecek kecukupan referensi (Mertens, 2005).

\section{HASIL DAN PEMBAHASAN Hasil}

Hasil penelitian yang diperoleh disesuaikan dengan rumusan masalah dan tujuan penelitian yang disampaikan dipendahuluan di atas. Secara umum hasil penelitian berupa informasiinformasi tentang permainan tradisional di Kalimantan Barat bagi pengembangan anak usia dini sebagai berikut.

Sejauh ini penelitian telah mengumpulkan 10 macam permainan yang dimainkan oleh anak. Berikut berikut ini adalah jenis-jenis permainan tersebut: Gasing, Jajak Sisir, Ukau, Jangkak Tempurung, Lantak/ leletop, Tabak Oka/ Dengkak, Jangko, Tikam Rusak, Galah Kepung/ Galasin, dan Tapok Beleg/ Kaleng.

Pembagian jenis permainan tidak rumuskan secara khusus. Namun, konsep bentuk permainan bentuk permainan yang ditemukan masuk dalam 2 (dua) kategori yaitu Solitary Play dan Cooperative Play. Solitary play. Jenis permainan ini adalah anak bermain sendiri dan tidak terlibat dengan anak lain. Bermain dengan mainannya sendiri merupakan tujuannya. Jenis solitary play ini terdapat dalam permainan seperti, ukau, jajak sisir. Cooperative play. Jenis Permianan ini memiliki aturan permainan dalam kelompok tampak lebih jelas pada permaiann jenis ini, dan punya tujuan serta pemimpin. Jenis permainan cooperative play dapat ditemukan dalam permainan berikut, seperti, gasing, tabak oka, lantak, galah kepung dan jangkak temupurung.

Permainan tradisional yang ditemukan oleh peneliti memiliki karakteristik yang beragam. Permainan tradisional sangat kental dengan interaksi sosialnya walaupun permainan tersebut dalam dimainkan secara individu. Sama halnya dengan permainan pada umumnya, permainan tradisional juga memiliki aturan yang melekat dalam permainan tersebut. Jika dimainkan secara berkelompok (Cooperatif play), aturan tersebut sesuai kesepakatan dan tradisi lokal setempat. Aturan main di beberapa tempat berbeda walaupun nama nya sama, seperti bermian gasing, tapok beleg, dan taba oka.

Permainan tradisional juga memiliki kekhasan dari komponen yang disajikan. Temuan peneliti menunjukkan permianan tradisional masing menggunakan media-media yang alami maupun barang bekas, dekat dengan lingkungan sendiri. Dalam bermain, biasanya permainan disertai dengan nyanyian (jajak sisir).

Beberapa permainan memerlukan lingkungan yang cukup luas karena benyak menggunakan aktivitas fisik, seperti tapok beleg dan galah kepong/ galasin.

Setiap permainan memerlukan media. Berdasarkan prinsip media pembelajaran, lingkungan dapat dikategorikan media pembelajaran. 
Lingkungan terbagi menjadi 2 (dua), lingkungan luar (outdoor) dan dalam (outdoor) ruangan. Permainan tradisional yang ditemukan dalam penelitian ini cukup banyak memanfaatkan lingkungan luar, seperti galah kepung, tapok beleg, gasing, jangkak tempurung, tabak oka, jangko, lantak, dan tikam rusak. Sedangkan permainan ukau dan jajak sisir dapat dimainkan di dalam rumah.

Klasifikasi media permainan cukup beragam, meliputi: media visual, audio, objek, audio visual, komputer. Dari permainan yang ditemukan, media permainan menggunakan objek. Objek yang digunakan bukan objek pabrikan, melainkan objek yang dikembangkan dan dimanfaatkan dari lingkungan anak. Objek media permainan berasal dari bahan alam dan barang bekas.

Seluruh permainan tradisional yang ditemukan oleh peneliti menggunakan media yang ramah lingkungan. Media permainan menggunakan bahan alam seperti daun, kayu, lidi, bamboo, biji-bijian dan batubatuan. Ada juga media permainan yang menggunakan barang bekas, seperti beleg (Kaleng).

Beberapa media permainan tradisional dari bahan alam langsung dimainkan oleh anak, seperti biji karet dalam permainan ukau dan batu untuk bermain tabak oka. Sedangkan dari bahan alam yang diolah/ dikembangkan oleh pemainnya berupa Gasing, lantak, jangkak, jangko, dan jajak sisir, dan tikam rusak. Beberapa media permainan tradisional yang menggunakan barang bekas seperti permainan Tapok Belek yang menggunakan bahan kaleng bekas.

Setiap permainan memiliki aturannya sendiri khususnya permainan dalam jenis cooperative play. Sedangkan untuk solitary play, aturan permainan melekat pada media permainannya sendiri. Aturan main berbeda-beda setiap daerah, tergantung kesepakatan yang dibuat oleh daerah yang menggunakan permainan tersebut. Langkah-langkah setiap permainan tradisonal yang ditemukan berbeda-beda. Khusus untuk permainan yang dimainkan secara cooperative play (kelompok) langkah-langkah yang dilakukan sebagai berikut. (1) Sekelompok anak membuat kesepakatan dalam permainan (sesuai pilihan jenis permainan). (2) Sekelompok anak menyepakati giliran dalam setiap permainan. Biasanya menggunakan permainan hompimpa atau cang kacang panjang. Secara bergantian melakukan permainan sesuai gilirannya. (3) Jika dilakukan dengan kompetisi, maka ada penilaian menang dan kalah setiap permainan baik individu per individu, atau kelompok per kelompok. (4) Jika permainan dilakukan secara kompetisi, maka setiap pemain yang menang mendapat apresiasi dari pemain yang kalah, dan biasanya mendapat hukuman (ditentukan di awal permainan) dalam bentuk gendongan, push up, ejekan. Dan (5) Permainan yang dilakukan secara solitery play tidak memiliki aturan kesepakatan, namun disesuaikan dengan kekhasan permainan itu sendiri. Permainan Ukau dapat dimainkan sendiri oleh anak, langkah-langkah permainan tersebut secara khas melekat pada setiap permainan. Setiap anak hanya menyiapkan media permainan dalam bentuk buah karet atau batu kerikil dengan jumlah variatif (biasanya berjumlah 5 buah). Setiap anak memainkan dengan cara melemparnya secara bergantian dengan jumlah yang diinginkan. Jika gagal melakukan langkah-langkah permainan, maka pemain akan mengulang permainan tersebut.

Permainan tradisional memiliki potensi yang sangat besar bagi pengembangan anak. Kegiatan bermain dapat pengembangan anak dapat mengoptimalkan semua potensi perkembangan yang dimiliki. Sebagian 
besar permainan yang ditemukan dalam jenis cooperative play kental dengan nilai sosialnya dan fisik motorik. Meskipun demikian, dari media dan proses bermainnya, permainan tradisional mengakomodir semua spek pengembangan. Pengembangan nilai agama dan moral dikembangkan melalui interaksinya dan aturan bermain yang disepakati bersama. Pemanfaatan bahan alam dan barang bekas bagian dari nilai moral dalam menjaga lingkungan. Khususnya dalam penggunaan bahan alam, refleksi dalam mengenal penciptaan terhadap lingkungan alam yang dimanfaatkan dalam kehidupan.

Pengembangan fisik dan motorik sangat dirasakan dalam setiap permainan tradisional. Bentuk keterampilan fisik motoric yang dikembangan dapat dilakukan dalam kegiatan melempar (ukai, tikam rusa, tabak oka, gasing, tapok beleg), berlari (galah kepong, tapok beleg), melompat (labak oka, jangkak tempurung, jangko), menjumput (jajak sisir, ukai), memukul (lantak/leletop).

Pengembangan kognitif dan bahasa dikembangkan melalui beberapa hal. Setiap permainan memiliki materi permainan dan aturan main. Pengetahuan anak tentang nomerik melalui urutan bermain, konsep angka dalam giliran, dan jumlah media, jumlah langkah, usaha mencapai kemenangan dalam bermain (kompetisi), focus pada sasaran yang dilempar (motorik dan kognitif). Upaya pengembangan potensi kognitif dn bahasa tersebut juga diperolah dalam kegiatan komunikasi yang dilakukan, cara-cara permainan, materi permainan, aturan permainan.

Potensi pengembangan sosial emosional dapat dilakukan melalui kesepakatan anak dalam bermain (tanggung jawab), kepemimpinan (koordinator permainan) dalam permainan kelompok, apresiasi dalam pencapaian permainan, interaksi sosial yang dengan saling menghargai aturan dan kesepakatan.

Dengan demikian permainan tradisional menjadi potensi pengembangan bagi anak usia dini yang komprehensif. Permainan juga sebagai media konservasi bagi kebudayaan daerah yang khas khususnya di Kalimantan Barat.

\section{Pembahasan}

Jenis-jenis permainan secara umum terdiri dari 6 karakteristik. Hal ini disampaikan oleh Parten, (1932) (dalam McDevitt \& Ormrod, 2016:567) bahwa aktivitas pengembangan sosial dalam enam bentuk kegiatan kegiatan bermain berikut: unoccupied: on looker play, solitary play, parallel play, associative play, cooperative play. Dari 10 permainan tradisional yang ditemukan dalam penelitian ini jenis permainan lebih dominan pada jenis solitary play dan cooperative play. Kedua jenis tersebut lebih menunjukkan permainan jenis cooperative lebih dominan. Hal ini menunjukkan bahwa permainan tradisional merupakan bagian dari media interaksi masyarakat dalam membangun nilai-nilai kebudayaan.

Permainan tradisional yang ditemukan merupakan media kearifan lokal dalam membangun komunikasi dan kebudayaan khas disetiap daerah. Parlebas (dalam Renson, 1991) “...modern sports tend to favour a rather undimensional type of play interactions, whereas traditional games often offer a much richer 'vocabulary' and 'grammar' of interpersonal communication forms...". Oleh karena itu, setiap permainan memiliki nalainilai kebudayaan yang menjadi media transformasi secara turun temurun. Media bukan hanya sebatas benda mati yang tidak memiliki nilai, melainkan sarana pendidikan. Setiap permainan yang dilakukan oleh sekelompok masyarakat merupakan menjadi refleksi nilai keanekaragaman budaya 
masyarakat. Hal itu diungkapkan dalam artikel 1 Deklarasi Universal tentang Keragaman Budaya UNESCO, 2001.

Karakteristik setiap permainan yang menjadi media konservasi budaya terintegrasi dalam media permainan, aturan permainan, dan lingkungan yang dimainkan. Setiap hal di atas merupakan produk kebudayaan dalam bentuk benda dan tak benda (aturan).

Jenis Media perminan sangat beragam. Jenis media terdiri dari media berbasis audio, media berbasis visual, media berbasis objek, media berbasis komputer. Jenis media permainan juga dapat berbasis manusia dan cetakan. Pada permainan tradisional yang ditemukan, media berbasis objek dan manusia lebih dominan ditemukan. Lingkungan juga sebagai media permainan bagi anak. Permainan yang dimainkan dalam bentuk kompetisi biasanya dilakukan di luar ruangan.

Media permianan yang digunakan sebagian besar berbasis objek. Objek yang dimainkan berupa bahan yang dikreasi oleh pemain sendiri. Umumnya media permainan yang dugunakan menggunakan bahan alam dan barang bekas.

Terkadang media permianan merupakan bagian dari pola kehidupan masayakat untuk beradaptasi dengan lingkungannya. Pemanfaatan media sebagai bagian dari pola kehidupan merupakan warisan nenek moyang yang secara turun temurun diwariskan. Pemilihan bahan dan penggunakan alat menentukan kualitas permainan dan nilai dari kebudayaan. Stanley Hall (dalam Zaini, 2018) mengemukakan sebuah teori yang dikenal dengan teori atavistis, yang berasal dari kata 'atavus' yang bermakna 'nenek moyang'. Menyebutkan bahwa di dalam permainan akan timbul bentuk-bentuk perilaku yang menggambarkan bentuk kehidupan yang pernah dialami oleh leluhur. Menurutnya "Ternyata, begitu satu permainan sama di semua wilayah maka semua wilayah itu satu keturunan yang sama, teori atavus begitu. Berarti, untuk menunjukan satu keturunan yang sama meskipun kita berbeda negara, agama, budaya, itu dengan permainan tradisional, itu entry point-nya," katanya.

Setiap permainan memiliki aturan mainnya masing-masing. Permainan dalam jenis cooperative play lebih ditentukan oleh kesepatan bermain yang dilakukan pemainnya. Sedangkan untuk solitary play, langkah-langkah permainan melekat pada media yang dimainkan. Kebebasan kreativitas dalam bermain lebih tampak pada jenis solitary play, dibandingkan dengan cooperative play. Langkah-langkah permainan solitary play disesuaikan oleh pemainnya.

Namun hal yang sebaliknya terjadi jika diharapkan interaksi sosialnya. Bermain cooperative play menekankan pada konservasi nilai-nilai sosial yang diwariskan dalam komuntasnya. Langkah-langkah permainan merupakan kesepakatan bersama. Kegiatan diawali dengan kesepakatan, dimainkan dengan aturan yang jelas secara bersama salng menghargai, dan kompetitif serta kerjasama dalam mencapai tujuannya, yaitu kemenangan.

Hasil penelitian dari 10 permainan yang ditemukan menunjukan kompleksitas dari tujuan pengembangan anak usia dini. Secara umum kita memahami bahwa anak memiliki potensi yang beragam. Di dalam system pendidikan kita disebutkan 6 aspek perkembangan. Dalam kegiatan permainan tradisional tersebut kesemua aspek dapat terfasilitasi.

Renson (1991) menyatakan “...been shown how traditional games have acted as a definite cultural identity...". Permainan tradisional menuntut komunikasi antar individu, dalam komunikasi ada transformasi budaya yang sangat kaya. Parlebas 
(dalam Renson, 1991) “...modern sports tend to favour a rather undimensional type of play interactions, whereas traditional games often offer a much richer 'vocabulary' and 'grammar' of interpersonal communication forms...". sejalan dengan pendapat di atas, (Norgaad, 2009) menyatakan "People not only speak their own linguistic language, which is different from others, they also use bodily language - in play and game". Dalam permainan yang ditemukan pemain tidak hanya berkomunikasi secara verbal, namun juga non verbal dalam bentuk bahasa tubuh dari kegiatan permainan dan aturannya. Pere Lavega (2014) menyatakan ada 4 potensi pengembangan yang secara tidak langsung dapat terfasilitasi.

Setiap permainan tradisional yang ditemukan, keterlibatan individu dalam permainan dapat mengembangan kemampuan dasarnya. Perihal ini didukung oleh pernyataan beberapa ahli yang rumuskan oleh Baek (2010:52) berikut.

"Game developers have argued that a good game is at the zone of proximal development (ZPD) or at the brink of zones of ability, cognition, and emotion" (Conati, 2002; Mallone \& Lepper, 1987; Rieber, 1996).

A moderately challenging game sustains engagement by providing accomplishment while maintaining effort. Success in the game environment breeds self-efficacy, which is highly correlated with interest in games (Zimmerman \& Kitsantas, 1997) as well as tutorial environments (Lepper et al., 1990) (dalam Baek, 2010: 52)

Oleh karena itu, permainan tradisional menjadi potensi dalam pengembangan anak usia dini yang komprehensif. Dengan demikian hal ini tentu linier dengan konteks kurikulum dan pendekatan yang dilakukan dalam pengembangan anak usia dini.

\section{SIMPULAN DAN SARAN Simpulan}

Penelitian ini menyimpulkan
bahwa permainan tradisional Kalimantan Barat menjadi potensi bagi pengembangan anak usia dini. Secara khusus tujuan yang diharapkan dalam penelitian ini sebagai berikut. Pertama, Jenis-jenis permainan yang ditemukan dalam sepuluh permainan tradisonal khas Kalimantan Barat terbagi dalam 2 jenis. Kedua jenis tersebut, yaitu solitary play dan cooperative play. Beberapa permainan juga dapat dikategorikan dalam kedua kategori tersebut secara bersama-sama. Kedua, karakteristik permainan tardisional yang ditemukan merupakan warisan budaya masyakat Kalimantan Barat. Kekhasan ditemukan dalam penyebuatan nama permainan, aturan permainan, media permainan dan lingkungan bermain. Ketiga, permainan tradisional khas Kalimantan Barat identic dengan pemanfataan bahan alam sebagai medianya. Sebagian media permainan juga berasal dari barang bekas. Media permainan ada yang hanya dimanfaatkan, dan ada pula yang dikembangkan secara khusus. Lingkungan media permainan sebagai media dilakukan di dalam dan luar ruangan. Keempat, Setiap permainan memiliki aturan bermainnya masingmasing. Langkah-langkah permainan dibedakan berdasarkan jenis permainnya. Permainan secara cooperative play dilakukan atas kesepakatan bersama oleh pemainnya. Sedangkan untuk solitary play disesuaikan keinginan pemainnya. Kelima, permainan tradisional memiliki potensi pengembangan anak usia dini. Dalam setiap permainan, 6 aspek pengembangan dapat terfasilitasi. Beberapa permainan dapat mengembangan keseluruhan aspek secara bersama-sama njika dimainkan dalam kelompok dan kompetisi.

\section{Saran}


Penelitian ini merupakan informasi yang akan disajikan melalui karya ilmiah berupa hasil penelitian dan draft naskah buku teks berupa bentukbentuk permainan tradisional khas Kalimantan Barat bagi pengembangan anak usia dini. Luaran penelitian ini dapat dikembangkan menjadi produk lain seperti, buku cerita, film, dan lainlain.

\section{DAFTAR RUJUKAN}

Badan Pusat Statistik, 2017 Provinsi Kalimantan Barat dalam Angka. BPS: Kalimantan Barat

Donna M. Mertens, 2005. Research and Evaluation in Education and Psychology: Integrating Diversity with Quantitative, Qualitative, and Mixed Methods, 2 nd Edition. New Delhi : Sage Publication India.

Judith Van Hoorn, Nourot, Scales, Alward, 2007. Play at The Center af The Curriculum. Pearson: Ohio

Kemdikbud, 2014. Permendikbud Nomor 137 tentang Standar Nasional PAUD. Kemdikbud: Jakarta

Laura E. Berk. 2004. Development Throught the Lifespan (Third Edition). Person Education, Inc. USA

Pere Lavega, José I. Alonso, Joseba Etxebeste, Francisco Lagardera \&
Jaume March, 2014. Relationship Between Traditional Games and the Intensity of Emotions Experienced by Participants. Routledge: London. Jurnal Research Quarterly for Exercise and Sport, http://www.tandfonline.com/loi/u rqe20.

Teresa M. McDevitt \& Jeanne Ellis Ormrod, 2016. Child Development and Education. Pearson Education: USA.

Redja Mudyahardjo, 2005. Filsafat Ilmu Pendidikan. PT. Remaja Rosdakarya: Bandung.

Umar Tirtarahardja \& Sulo La Sulo, 2005. Pengantar Pendidikan. Rineka Cipta: Jakarta

Yoga Awalludin Nugraha, Eko Handoyo \& Sri Sulistyorini, 2018. Traditional Game on The Social Skill of Students in The Social Science Learning of Elementary School. UNESA: Semarang. Journal of Primary Education https://journal.unnes.ac.id/sju/ind ex.php/jpe/article/view/23475

Young Kyun Baek, 2010. Gaming For Classroom based learning. IGI Global: New York.

Yuliani Nurani Sujiono, 2009. Konsep Dasar PAUD. Indeks: Jakarta 